\title{
LEADERSHIP STYLE OF THE HEADMASTER IN IMPROVING QUALITY OF EDUCATION IN SMK AL-FAQIH SUMBER NYAMPLONG KOWEL PAMEKASAN.
}

\author{
Abdul Halim \\ firdi_halim@yahoo.co.id \\ Islamic Education Studies Program Post-Graduate Program University of Muhammadiyah \\ Surabaya
}

\begin{abstract}
The formulation of problem in this thesis research can writer describe as follows: first, how to apply principal leadership style in improving quality of education at SMK Al-Faqih Sumber Nyamplong Kowel Pamekasan? Second, How pattern of improvement of management of education quality strategy at SMK Al- Faqih Sumber Nyamplong Kowel Pamekasan? Third, how are the principal leadership style steps in improving the quality of education in SMK Al-Faqih Sumber Nyamplong Kowel Pamekasan?

This research is a research that uses qualitative approach, that is research procedure that produce descriptive data in the form of written words or oral from people or behavior that can be observed. The type of this research is phenomenology, that is the researcher try to explain about the implementation field and systematic leadership style which done by the principal in improving the quality of education in SMK Al-Faqih Sumber Nyamplong Kowel Pamekasan.

The research findings in this thesis can be summarized: First: The leadership style applied by the principal's leadership is a democratic leadership style, and in this case the principal applies his leadership style to the three basic patterns of duty, achieved. By using movement from button up and top down; Second: The headmaster of SMK Al-Faqih Sumber Nyamplong Kowel Pamekasan has the characteristics of spiritual leadership based on true ethics of honesty, fairness, the spirit of pious charity, the beloved leader, talk little and casual work and so on; Third: In improving the management of quality education strategy of SMK Al-Faqih Sumber Nyamplong Kowel Pamekasan principals cling to the 5 pillars of TQM, while the teachers develop management through the vision of institutional mission that is cooperation with the team, involvement stakeholders, student involvement and parental involvement.
\end{abstract}




\section{INTRODUCTION}

Education is a process that aims. Any process that aims of course has a size already up where our journey in reaching the goal. In contrast to physical goals such as distance of a place or a production target, the goal of education is an intangible and constantly changing and increasing ". ${ }^{1}$

In this case the 1945 Constitution has formulated an ideal goal that is the intellectual life of the nation. The national education system is an effort to realize the ideal ideals is an intelligent Indonesian citizen. To find out the extent to which the intelligent human achievement that we can see in the reality of everyday life in the community with Indonesia. ${ }^{2}$ And the national education system requires standards. The standard is not a standard in a rigid sense but a constantly increasing standard. So, the need for standardization of national education get a positive response. ${ }^{3}$

In this case Leadership is the ability to create the most effective change in group behavior; for others he is the process of influencing group activities toward goal setting and goal achievement. ${ }^{4}$ Most people think that leadership is regarded as the ability to achieve position, not to gain followers. Thus, they only pursue position, rank or position and after they succeed they think they are already leaders.

Such perceptions have implications for two general problems: (1) those with a leader are often frustrated Due to lack of followers (or support / support), (2) those who have no official position (leader status) may not see themselves as leader, thereby not developing leadership skills. ${ }^{5}$

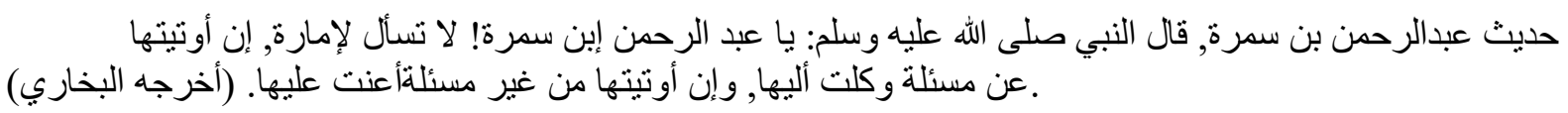

"Hadith narrated by Abdurrahman bin Samurah, he said: has said Prophet SAW: O Abdurrahman do not expect a position. Indeed, if the office is given because of your ambitions you will bear all the burden. But if you are assigned without your ambitions then you will be helped by Allah SWT to overcome them."6

Some styles or styles of leadership that many influence a leader's success in influencing the behavior of his followers. The term style is roughly the same way the leader used to influence his followers. And if it happens in a particular organization, and the person needs to develop staff and build a motivational climate that produces a high level of productivity, then the person needs to think about his leadership style. Leadership style is a behavioral norm used by a person when the person is trying to influence others as he or she sees. In this case the effort to align perceptions among people whose behavior will be influenced will be of paramount importance. ${ }^{7}$ In the letter of Al-'imron (3) verse 26:

\footnotetext{
${ }^{1}$ Tilaar, Standarisasi Pendidikan Nasional, (Jakarta: Rineka Cipta, 2006), 75.

2 Ibid., 76.

${ }^{3}$ Pendapat-pendapat yang menonjolkan nilai positif dari standard dalam pendidikan, lihat antara lain Douglas B. Reeves, The Leader's Guide to Standard, A Blueprint for Educational Equity and Excellence, 2000, 89-94

${ }^{4}$ Rohiat, Kecerdasan Emosional Kepemimpinan Kepala Sekolah (Bandung: Refika Aditama, 2008), 14.

${ }^{5}$ Abdul Mu'in, Kepemimpinan Pendidikan, (Malang: CV Ismaya Berkah Group, 2016), 1.

${ }^{6}$ Al-Hadist, Imam Bukhari (كتب الأيمان و النذور), 83.

${ }^{7}$ Abdul Mu'in, Kepemimpinan, 56.
} 


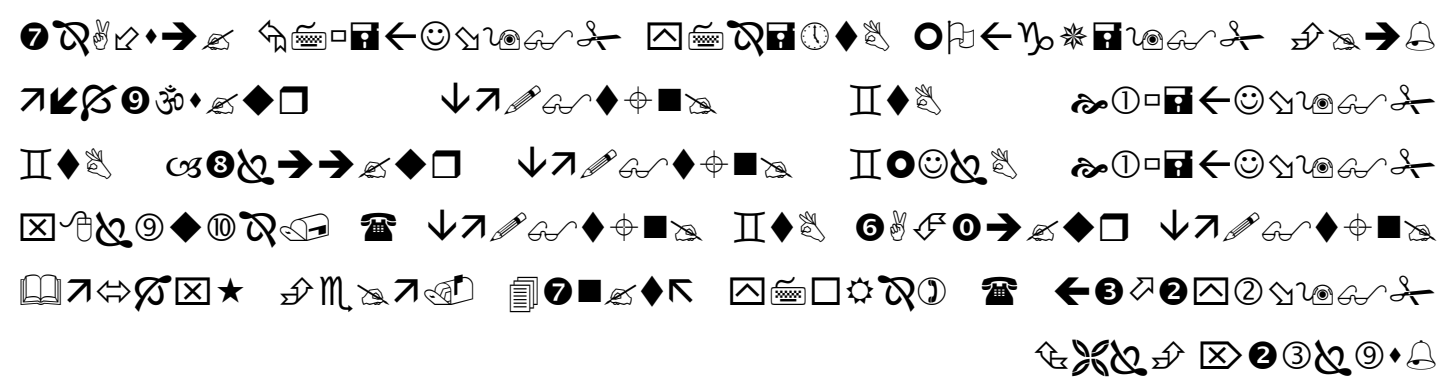

"Say (Muhammad)," O god of the possessor of power, you give power to whomever you wish. You glorify whomever you wish and despise whomever you wish. In your hands all virtues. Truly you are all-powerful over all things ". ${ }^{8}$

Leadership emphasizes efforts to achieve goals together with others through discipleship. The following is the meaning of leaders and members into one vision, mission, and purpose so that members become more (a) able to perform their duties, (b) future orientation, and (c) oriented to the demands of change. ${ }^{9}$

The principal is one component of education that plays a role in improving the quality of education. As Supriadi pointed out that: "the close relationship between the quality of school principals with various aspects of school life such as school discipline, school culture climate, and decreased misbehavior of learners". In the meantime, the principal is responsible for the management of micro-education, which is directly related to the learning process at school. As stated in Article 12 paragraph 1 of PP 28 of 1990 that: "principals are responsible for the implementation of educational activities, school administration, education of other educational facilities, and the utilization and maintenance of facilities and infrastructure". ${ }^{10}$

Regulation of the minister of national education number 63 of 2009 on the quality assurance system of education in the Constitution. 20 years 2003 on National education system article 1 verse 2 "quality assurance of education is systematic and integrated activity by education unit or program, unit organizer or education program, local government, government and society to raise the level of intelligence of nation life through education". Article 2 paragraph 1 explains "the ultimate goal of guaranteeing the quality of education is the high intelligence of human life and the nation as aspired by the opening of the 1945 Constitution of the Republic of Indonesia". ${ }^{11}$

Quality of education as an indicator to see productivity and closely related to management or management issues in institutions or schools. This can be attributed to the statement "quality failure in an organization caused by management flaws"). ${ }^{12}$ One of the failures in improving the quality is the manager has no insight to improve the quality system and never follow the training on how to improve the quality system and not follow the upgrades given. ${ }^{13}$

There are two factors that can explain why the effort to improve the quality of education has been less or unsuccessful. First, education development strategy so far is more input oriented. Such a strategy is more standardized to the assumption that when all educational inputs have been met, such as the provision of books (teaching materials) and other learning

\footnotetext{
${ }^{8}$ Al-Quran, 3 (Al-Imron): 26.

${ }^{9}$ Badeni, Kepemimpinan dan Perilaku Organisasi, (Yogyakarta, Ar-Ruzz Media, 2013), 130.

${ }^{10}$ Mulyasa, Menjadi Kepala Sekolah Professional, (Bandung: Remaja Rosdakarya, 2005), 24-25.

${ }^{11}$ UUD No.20 Tahun 2003. Penyelenggaraan Pendidikan Serta Wajib Belajar (Bandung: Citra Umbara, 2010), 386-391.

12 Rohiat, Kecerdasan, 19.

13 Ibid., 20.
} 
tools. Provision of educational facilities, teacher training and other education personnel, automatically education institutions (schools) will be able to produce the output (output) quality as expected. It turns out that the input-output strategy introduced by the theory of education production function is not fully functional in educational institutions (schools), but occurs only in economic and industrial institutions. ${ }^{14}$

With regard to quality assurance of education by closer external education (especially parent and community) customers, their aspirations will be more accommodated, as well as accountability control can be done fairly. The problem is, how to ensure quality disbelief caused by the emergence of local criteria. Furthermore, it is necessary to consider and effectively disseminate the National Education standard (SNP / PP No. 19/2005) to all local governments and educational units in each region so that they can compete competitively in national, even international contexts. ${ }^{15}$

To create a good quality of education, it is not easy. In addition to requiring complete facilities is also very necessary manager of a reliable and professional, especially the teachers as the main character. Both of the above are absolutely necessary to realize a quality educational institution. Therefore, an educational institution should strive to make improvements, both in relation to the revamping of its management personnel: such as principals, teachers' boards, and administrative staff, as well as concerning improvements to the facilities and infrastructure used in the implementation of education.

Success or failure of education and learning in schools is influenced by the ability of the principal in managing each component of the school (who is behind the school). The principal's abilities are primarily concerned with their knowledge and understanding of management and leadership, and the tasks assigned to them. ${ }^{16}$

The importance of the principal's leadership style when able to plan, coordinate, and organize the source to be efficient and successful in order to survive and thrive in a competitive environment, and in the operational and efficient management of school-related components. Which success is viewed from three sides, input, process, and output. So that the quality of previous education is still low in the future will be more qualified.

Based on the above background, the authors are interested to conduct research in SMK Al-Faqih Sumber Nyamplong Kowel Pamekasan premises: "Principal Leadership Style in Improving Education Quality in SMK Al-Faqih Sumber Nyamplong Kowel Pamekasan".

\section{RESEARCH FOCUS}

Based on the introduction as mentioned above, the writer can formulate the focus of research, as follows:

1. How is the application of headmaster's style in improving the quality of education in SMK Al-Faqih Sumber Nyamplong Kowel Pamekasan?

2. What is the pattern of improving the management of quality education strategy at SMK Al-Faqih Sumber Nyamplong Kowel Pamekasan?

3. How are the principal leadership style steps in improving the quality of education in SMK Al-Faqih Sumber Nyamplong Kowel Pamekasan?

\footnotetext{
${ }^{14}$ Aminatul Zahroh, Total Quality Manajement, (Yogyakarta: Ar-Ruzz Media, 2014), 18.

15 Rohiat, Kecerdasan, 3.

${ }^{16}$ Mulyasa, Manajemen dan Kepemimpinan Kepala Sekolah, (Jakarta: Bumi Aksara, 2015), 5.
} 


\section{RESEARCH METHODS}

This research is a research that uses qualitative approach, that is research procedure that produce descriptive data in the form of written words or oral from people or behavior that can be observed. With respect to this context, qualitative methods are "research procedures that produce qualitative data containing expressions or records of the person himself or their observed behavior". ${ }^{17}$

Researchers use a qualitative approach caused by several considerations that this study was conducted based on the natural setting, this study using human, in this case the researcher as the main instrument, the data collected in the form of speech and action, and data analysis performed inductive.

The type of this research is phenomenology, that is the researcher try to explain about the implementation field and systematic leadership style which done by the principal in improving the quality of education in SMK Al-Faqih Sumber Nyamplong Kowel Pamekasan. In qualitative research, the main data obtained is in the form of words through interview activities, the rest are additional data such as observation and documentation. As Lofland says that "the main data source in qualitative research is the words, and the rest of the action is additional data such as documents and others". ${ }^{18}$

The Source of data in qualitative research can be obtained from people and not people. The person who became the source of data in this study is the principal, waka curriculum, students, and some teachers at SMK Al-Faqih Sumber Nyamplong Kowel Pamekasan. Further data obtained are formulated in the form of interview transcript and field observation note. While the data source is not the person in this study obtained by recording the existing documentation at SMK Al-Faqih Sumber Nyamplong Kowel Pamekasan.

Data collection procedures used in this study are observation, in-depth interviews and documentation.

\section{ANALYSIS / RESULTS OF RESEARCH}

To find out how the leadership style of school principals in improving the quality of education in SMK Al-Faqih Sumber Nyamplong Kowel Pamekasan, the researchers conducted interviews to the principal father, Mr. Drs. Moh. Sale, M.Pd.I who is the principal who is respected and respected by his subordinates because of his wisdom in leading and right on the target. He answered firmly questions from the researcher on what is related to the style of leadership in improving the quality of education, following exposure:

"To be a leader is not easy, because in leading an institution that would require followers who trust in me, in that lead I have 4 (four) archetype that is:

First; attachment to tasks, it is part of my duty as principal to provide guidance and to provide direction to teachers or subordinates who lack understanding of the problem of their work, make a decision by deliberation and mutual consensus, provide direction first when there is one teacher who often come late, after that we just return the responsibility to the teacher's personal self,

\footnotetext{
${ }^{17}$ Robet Bogdan dan Steven J. Taylor. Kualitatif Dasar-Dasar Pendidikan (Surabaya: Ed. A. Khozin AfandiUsaha Nasional), tt. 30 .

${ }^{18}$ Laxy J. Moleong. Metode Penelitian Kualitatif, (Bandung: Remaja Rosda Karya, 2001), 122.
} 
Second; concerned with cooperative relationships, i.e. here I use two movements between top down and button up to maintain cooperative relationships with subordinates.

Third; emphasize the results achieved, because here the style that nurturing of a leader greatly affect the results of school achievement and achievement of learners, strategy management I use to improve the quality of education that is with the leader who trusted first by followers and the environment, then the existence of the products we have in this institution we offer to the public so that the community is able to be interested in our products, and in proceed by the process or good management by working together with subordinates or staff of teachers and administration, and.

Fourth; is my firm commitment. That's how I manage the quality of education until now can be said that the quality of existing increasingly increasing and quality. This can be seen from the achievement of the school so as to gain the trust of the community and the achievements of students who have been achieved until the school of SMK Al-Faqih Sumber Nyamplong Kowel Pamekasan within 2 years has been accepted by the community achievement is quite good. Thankfully, related to the relationship between the leadership style of the principal to the improvement of the quality of education in SMK Al-Faqih Sumber Nyamplong Kowel Pamekasan, it must exist and very influential, leadership style is driven through top down and hard work provides a good role model, gave birth to its own creativity on the teacher itself. In this case, the principal must be able to become a team supervisor consisting of teachers, staff, and students in realizing effective and efficient teaching-learning process to achieve learning productivity that can ultimately improve the quality of education". ${ }^{19}$

After conducting an interview with the principal, the researcher was not satisfied with what has been expressed by the father of the principal, then at the same time the researchers conducted interviews to the curriculum waka Akhmad Holid Basit, M. Si, following his explanation:

"I realized that the principal's leadership style here is very good and really protects, in making a decision he does not prioritize the power he possesses, but he is deliberately joint and is done flexibly and not rigidly, nor is it in a cooperative relationship with his followers and his subordinates, he used top down and button-up movements, so that in every lead he did not make unilateral decisions but still gave option opportunities to followers and other subordinates ie teachers and staff, not only when his subordinates faced difficulties in the headmaster's work provides direction and guidance, so that the pattern of quality improvement of education in SMK Al-Faqih Sumber Nyamplong Kowel Pamekasan not separated with the principle of quality itself that is parents, society, business, and education, in accordance with the mission and vision set. As for the management is given authority to 4 helpers namely curriculum, student affairs, facilities and public relations. Curriculum used in our school is curriculum KTSP Software Engineering, facilities we provide for learners is a board, and LCD projector 3 pieces, computer laboratories 20, libraries, etc., the relationship of headmaster leadership style to improve the quality of education is very influential, because with the leadership that has been applied and explained above make SMK Al-Faqih Sumber Nyamplong Kowel Pamekasan increasingly known by the community even though its presence is not in the middle of the city, because the practiced management is able to advance the creativity and liveliness of learners and the intelligence of his EQ." 20

\footnotetext{
${ }^{19}$ An interview with the headmaster of SMK Al-Faqih Sumber Nyamplong Kowel Pamekasan, on July 17, 2017.

${ }^{20}$ An interview with the curiculum staff of SMK Al-Faqih Sumber Nyamplong Kowel Pamekasan, on July 17, 2017.
} 
The next day, because the researcher still did not feel enough to the results that have been obtained in the interview to the principal with waka curriculum, the researcher continues the research with a complete interview until the researchers feel completely satisfied that the data is saturated. On Tuesday, July 18, 2017, the researcher conducted a third interview, this was done to Nurul Fitriatis Suroh, as a teacher at SMK Al-Faqih Sumber Nyamplong Kowel Pamekasan. Here's the explanation:

"Relating to the implementation of the principal's leadership style in improving the quality of education cannot be separated from the behavior of leaders who created the wise, fair, independence in work, spiritual level is also high. In a relatively young period of time SMK Al-Faqih Sumber Nyamplong already able to take action as well as established schools around us. Even already can include students to participate in East Java regional leveling contest. if there is a problem that must be solved together, then the deliberation and mufakatlah done by the principal. The principal can also be said to be a wise leader because he does not perform his duties by himself but he distributes duties and responsibilities to his subordinates in charge of teachers and staff of SMK Al-Faqih Sumber Nyamplong Kowel Pamekasan, the pattern of quality management education management in SMK Al -Faqih Nyamplong Kowel Pamekasan's Sourcer is started with teamwork, while strategies to improve team performance in achieving goals include problem solving skills, skill in dealing with confrontation, assessment / action, appreciation and others. Furthermore, the involvement of stakeholders, the users of education services, then the involvement of students, because students need maximum service, and parent involvement, because parents in education is needed by schools or educational institutions. With the inclusion of race students in the regional level, it has been shown that it is obtained because of the support and management of the principal in managing, planning, organizing the employee to be efficient and successful to survive and develop amid a competitive environment, and in the management operationally and efficiently to school-related components. And the success can be viewed from input, process, and the output". ${ }^{21}$

There are still irregularities of researchers when the results of interviews of the three informants who have done, the researchers feel the data that have been generated from the three informants it seems the results have not been declared credible. So, at the same time the researchers conducted an interview to one of the students at SMK Al-Faqih Sumber Nyamplong Kowel Pamekasan, following exposure:

"The application of leadership style of headmaster at SMK Al-Faqih Sumber Nyamplong Kowel Pamekasan, i.e. if there are things that have urgent then directly executed, then if there are things that still need to be punctured it will seek opinions from the board of teachers, then the talks both spoken by the principal both when giving speeches and discourse at the ceremony or teaching in the class, the sentences are easy to digest and easily understood by the students, the principal is also never bored and tired always give direction and guidance to us about what we should do and what we should not do, to improve the management of quality strategies especially to learners should be given special guidance for children who excel. The relationship between the principal's leadership style and the pattern of quality improvement of education is very existent, because with the character of leadership is firm and straightforward then subordinates will carry out the task as much as possible and it can be realized if the principal is firm. "22

\footnotetext{
${ }^{21}$ An interview with the teacher of SMK Al-Faqih Sumber Nyamplong Kowel Pamekasan, on July 18, 2017.

${ }^{22}$ An interview with the students SMK Al-Faqih Sumber Nyamplong Kowel Pamekasan, on July 18, 2017.
} 
After the researchers conducted interviews with several informants, and researchers feel they have assumed the data obtained is credible, the researchers made observations as a proof of the results of data exposure by some informants.

On Saturday July 25, 2017, precisely at 11:00 pm the researchers visited the school of SMK Al-Faqih Sumber Nyamplong Kowel Pamekasan to make observations. At that time, I entered the living room, see the vision and mission that has been embedded in the building, that becomes the center for education and learning in the superior information technology and communication expertise in Indonesia. While in view of its mission produce middle-level human source mastering computer technology ready to use, competitive power in the job market, independent, proactive and productive and generate high-level human source who have competence knowledge computer technology, social competence and personal competence of faithful, priority on good morality. Then I entered the waka curriculum room at that time also the principal's father was in the waka curriculum room, saw the father who was then serving one of the assistant curriculum who had difficulty in completing the task, then the principal's father provides guidance and direction guidance.

The style of the headmaster by using the combined movement of button up with top down is clearly visible when at that time the researcher sees the school will follow a preparatory race event in order to the 72nd anniversary of the Republic of Indonesia in Pamekasan Regency which hopefully is still in process then the principal throwing it all together with deliberations, related to the students to be delegated. and it is one of the top down motions, one of the button up motions when on Monday in the ceremony of the headmaster pointed one of the teachers to fill the message to the students of class XII. ${ }^{23}$

To check the validity of the data and to prove the data's credibility, the researchers went to the vocational school of Al-Faqih Sumber Nyamplong Kowel Pamekasan again to do triangulation of some data that has been analyzed either pre-field, field process or after field, on Monday 31 July 2017 at 09.00 WIB place guest room. Whereas after the result of data analysis, I have interpreted by using interprets personally but not out of research result in field, then triangulation with informant concerned those are principal, waka curriculum, teacher, and student. Thankfully, interpretation results that have been in stacking about the style of leadership of the principal in improving the quality of education in SMK Al-Faqih Sumber Nyamplong Kowel Pamekasan stated, the style of leadership of the principal at SMK Al-Faqih Sumber Nyamplong Kowel Pamekasan apply type of democratic leadership style. All of his decicion is decided through consensus and mutual consent. And in his leadership using the movement of button up and top down. The level of management of the principal's quality strategy rests on the five pillars of TQM, namely products, leaders, organizations, processes and commitments. Implementation of its management through the vision of the mission of educational institutions that is by paying attention to teamwork, involving stakeholders, involving students and involving parents, so the relationship between the leadership style of the principal to the pattern of improving the quality of education management in SMK AlFaqih Sumber Nyamplong Kowel Pamekasan very influential, because the leadership style of the principal is very big influence and becomes an important factor to quality improvement. And of all the results of the above analysis is real and can be tested its validity with the truth and has been considered credible.

From the results of our research through the instruments of observation, interview, documentation and triangulation research sites at SMK Al-Faqih Sumber Nyamplong Kowel

\footnotetext{
${ }^{23}$ An observation result from SMK Al-Faqih Sumber Nyamplong Kowel Pamekasan, on July 25, 2017.
} 
Pamekasan researchers trying to explain and answer what researchers have found with some data in the field.

Departing from here, researchers try to describe the data that researchers find based on logic and reinforced with existing theories that are then expected to find something new. In accordance with the analytical techniques that researchers have pointed out that researchers use descriptive qualitative analysis techniques (describe) to explain all the findings that already exist, whether it is from observations, interviews, documentation, and triangulation. The discussion also based on the findings of the research obtained are as follows:

1. Applying Head Leadership Style at SMK Al-Faqih Sumber Nyamplong Kowel Pamekasan

The leadership style applied by the principal is a democratic leadership style, and in this case the principal applies his leadership style to the three basic patterns of duty, importance to cooperative relationships, and attach importance to achievement. using movement from button up and top down.

This is reinforced by the theory that refers to the theme of research above, The kind of good leadership and appropriate today is democratic leadership. All teachers in school work to achieve common goals. All decisions are taken through deliberation and consensus and must be obeyed. The leader respects and respects the opinions of each teacher and provides opportunities for teachers to develop their initiative and creative power.

The democratic leader does not perform his own duties, he is wise in the division of work and responsibility. It can be argued that the responsibility lies in the shoulders of the entire board of teachers, including the school leader, he is welcoming and always willing to help his subordinates by giving advice, advice, and required advices. Under his leadership teachers work with joy to advance school education. All work is carried out in accordance with a plan that has been considered and agreed upon. Finally, create a healthy and fun family atmosphere. School leaders are considered as a father, brother or sister who can put themselves in accordance with the conditions and circumstances of the environment. ${ }^{24}$

The headmaster has been leading SMK Al-Faqih Sumber Nyamplong Kowel Pamekasan for 2 years, in good leadership and trusted, he leads due to talent and gene factors, it includes Ecological Theory. This ecological theory essentially means that a person will only succeed to be a good leader if he has a leadership talent. The talent is then developed through regular education and experience that allows for further development. ${ }^{25}$

2. Improved Pattern Management Quality Management Strategy at SMK Al-Faqih Sumber Nyamplong Kowel Pamekasan

Leader (headmaster) at SMK Al-Faqih Sumber Nyamplong Kowel Pamekasan has characteristic spiritual leadership based on true ethics of honesty, fairness, spirit of charity, beloved leader, little talk much work and relax and so on.

Prijosaksono put forward the concept of Q-Leader. In line with the concept of multiple quotient. Q in Q Leader means a leader who has IQ, EQ and SQ. The spiritual leadership referred to in this paper is paradigmatic to religious ethics in its leadership behavior. The religious ethics referred to here is not merely the ethics explored from religious beliefs, but also the ethics born of a spiritual leader, a spirituality that lives in daily activities. Because religion is primarily an organized religion is usually associated with organized aspects of spirituality which include a set of rules, faiths and traditions.

\footnotetext{
${ }^{24}$ Soekarto Indrafachrudi. Bagaimana Memimpin Sekolah Yang Efektif (Bogor: Ghalia Indonesia, 2006 ), 22.

${ }^{25}$ Yasmil Anwar dan Adang. Sosiologi Untuk Universitas (Bandung: PT, Refika Aditama, 2013). $243-244$.
} 
In improving the management of quality education strategy of SMK Al-Faqih Sumber Nyamplong Kowel Pamekasan principals cling to the 5 pillars of TQM, while the teachers develop management through vision of institutional mission that is cooperation with team, steakholders involvement, student involvement and parent involvement.

There are at least four criteria for a successful TQM program implemented by a company. The four criteria are as follows (Creech, 1996: 4).

a. TQM should be based on awareness of quality and quality oriented in all of its activities throughout the program, including in every process and product.

b. TQM must have a strong humanitarian nature to bring quality to the way employees are required, engaged, and inspired.

c. TQM should be based on a decentralized approach that delivers authority at all levels, especially on the front lines, so enthusiasm for mutual involvement and goals becomes a reality, not just an empty slogan.

d. TQM should be applied thoroughly so that all principles, wisdom and habits reach every corner and gap of the organization.

3. steps of principal leadership style in improving the quality of education in SMK AlFaqih Sumber Nyamplong Kowel Pamekasan

As for the steps taken by the principal in order to improve the quality of education are as follows:

a) Provide of infrastructure.

Provide of facilities and infrastructure is a necessity in order to guarantee the quality of education. In this case the principal completes the necessary educational facilities and students there are computer lab with 20 computers, LCD projector pieces, classrooms, libraries and so on.

Input education in the form of source and software has been prepared, is the process of input, both from decision-making, institutional management process, program management has been organized optimally until its output can be measured from the quality, effectiveness, productivity, efficiency, innovation, quality of life works, and his work morale.

b) Supervise every semester and every year.

Supervise and evaluation of teachers every month and discussed is about learning and work programs.

Besides being a supervisor, the principal must also be able to become an evaluator for the programs that have been implemented. Evaluation is necessary to influence the level of achievement of predetermined objectives. All implementation of a work plan that has been realized regularly should be evaluated.

\section{Conclusions}

a) The application of the leadership style applied by the headmaster at SMK Al-Faqih Sumber Nyamplong Kowel Pamekasan that the style of leadership is the overall pattern of the actions of a leader, visible and invisible by his subordinates. The applied leadership style is the application of democratic leadership style. All decisions he decided through discussion and mutual consent. And in his leadership using the movement of button up and top down. Likewise, with the spiritual level of leaders who bring the dimension of the world to the spiritual dimension (divinity). God is the true leader, who inspires, influences, serves and moves the conscience of His servant in a wise way through an ethical and exemplary approach. Therefore, spiritual leaders are also called leadership based on religious ethics. 
b) The pattern of improving the management of the quality of education strategy in SMK AlFaqih Sumber Nyamplong Kowel Pamekasan, in the context of education, the definition of quality includes input, process, and output. The input in terms of source and software is ready in the process, the vision is already embedded and already impregnated by the existing components, evidenced by the process and its output. In a relatively young timeframe, there has been a wide range of achievements that students have achieved. The management level of the principal's quality strategy rests on the five pillars of TQM: products, leaders, organizations, processes and commitments. Implementation of its management through vision and institutional mission of education that is by payying attention to the teamwork, involving the stakeholder, involving students and involving parents.

c) The relationship of headmaster leadership style to the pattern of quality improvement of education in SMK Al-Faqih Sumber Nyamplong Kowel Pamekasan very influential, because the leadership style of headmaster is very influential big and become important factor to quality improvement of quality. And because in modern management a leader must also act as a manager, judging from the management functions of planning (planning), organizing (organizing), controlling (supervision), and actuating.

\section{References}

Abdul Mu'in, Kepemimpinan Pendidikan, (Malang: CV Ismaya Berkah Group, 2016).

Al-Hadist, Imam Bukhari (كتب الأيمان و النذور),

Al-Quran, 3 (Al-Imron)

Aminatul Zahroh, Total Quality Manajement, (Yogyakarta: Ar-Ruzz Media, 2014).

Badeni, Kepemimpinan dan Perilaku Organisasi, (Yogyakarta, Ar-Ruzz Media, 2013).

Laxy J. Moleong. Metode Penelitian Kualitatif, (Bandung: Remaja Rosda Karya, 2001).

Mulyasa, Manajemen dan Kepemimpinan Kepala Sekolah, (Jakarta: Bumi Aksara, 2015).

Mulyasa, Menjadi Kepala Sekolah Professional, (Bandung: Remaja Rosdakarya, 2005).

Robet Bogdan dan Steven J. Taylor. Kualitatif Dasar-Dasar Pendidikan (Surabaya: Ed. A. Khozin AfandiUsaha Nasional), tt.

Rohiat, Kecerdasan Emosional Kepemimpinan Kepala Sekolah (Bandung: Refika Aditama, 2008).

Soekarto Indrafachrudi. Bagaimana Memimpin Sekolah Yang Efektif (Bogor: Ghalia Indonesia, 2006 ).

Tilaar, Standarisasi Pendidikan Nasional, (Jakarta: Rineka Cipta, 2006). 
UUD No.20 Tahun 2003. Penyelenggaraan Pendidikan Serta Wajib Belajar (Bandung: Citra Umbara, 2010).

Yasmil Anwar dan Adang. Sosiologi Untuk Universitas (Bandung: PT, Refika Aditama, 2013). 